\title{
Surgery is the preferred treatment for bile duct hamartomas
}

\author{
XIAO-YU YANG ${ }^{1 *}$, HAI-BO ZHANG ${ }^{2 *}$, BIN WU $^{1}$, AI-JUN LI ${ }^{1}$ and XIAO-HUI FU ${ }^{1 *}$ \\ ${ }^{1}$ Division of Special Treatment II, Eastern Hepatobiliary Surgery Hospital, Second Military Medical University, \\ Shanghai 200438; ${ }^{2}$ The First Department of General Surgery, Cixian People's Hospital, Handan, Hebei 056500, P.R. China
}

Received January 28, 2017; Accepted July 22, 2017

DOI: $10.3892 / \mathrm{mco} .2017 .1354$

\begin{abstract}
Bile duct hamartoma (BDH) is a rare liver disease with a rising incidence in recent years. A retrospective study on BDH patients between June 2007 and December 2015 was conducted. All the medical records, including clinical, imaging and pathological characteristics, were retrieved. Follow-up data were obtained by telephone communication. The majority of the patients had no symptoms and the laboratory tests were normal. The appearance on ultrasound examination was variable. The lesion exhibited low density on plain computed tomography and no enhancement in 4 cases, and inhomogeneous enhancement in 1 case. Magnetic resonance imaging examination revealed hypointensity on T1-weighted imaging (WI), hyperintensity on T2WI, no enhancement in 1 case, and enhancement in 4 cases. Two patients underwent magnetic resonance cholangiopancreatography due to jaundice and intrahepatic bile duct dilation. The preoperative diagnosis was liver cancer in 4 cases, hepatic hilar biliary obstruction in 1 , chronic calculous cholecystitis in 1, suspected hepatic abscess in 1, and benign liver tumor in 2 cases. All the patients underwent surgery. Nest-like cell arrangements were observed in 2 patients, and in 1 patient the lesion transformed to intrahepatic cholangiocarcinoma, resulting in the patient's death 25 months after surgery. Thus, BDH may transform into a life-threatening cholangiocarcinoma and it should be surgically removed. Furthermore, the mechanism underlying carcinogenesis in $\mathrm{BDH}$ requires further investigation.
\end{abstract}

\section{Introduction}

Bile duct hamartomas (BDH), also referred to as von Meyenburg complex (VMC), were first described in 1918 (1),

Correspondence to: Professor Xiao-Hui Fu, Division of Special Treatment II, Eastern Hepatobiliary Surgery Hospital, Second Military Medical University, 225 Changhai Road, Shanghai 200438, P.R. China

E-mail: ehbh_fxh@163.com

*Contributed equally

Key words: bile duct hamartoma, treatment, surgery, diagnosis, prognosis with a reported incidence of $5.6 \%$ in adults and $0.9 \%$ in children (2). An increasing number of patients with BDH may be diagnosed with the development of imaging modalities. In the past, when the diagnosis of $\mathrm{BDH}$ relied on pathological examination following liver biopsy, it was considered to be a benign disease, managed by regular observation rather than surgery. However, in recent years, an increasing number of cases demonstrated that there is a possible association between BDH and intrahepatic cholangiocarcinoma (3-5). Therefore, BDH should be resected when possible. Thus far, whether BDH patients should undergo surgical treatment remains controversial. The aim of the present study was to retrospectively investigate $9 \mathrm{BDH}$ cases in our hospital to highlight the importance of surgical treatment for $\mathrm{BDH}$.

\section{Patients and methods}

Study design. A retrospective study on patients who were diagnosed with BDH between June 2007 and December 2015 at the Eastern Hepatobiliary Surgery Hospital (Shanghai, China) was conducted. The medical records of these patients, including clinical, imaging and pathological characteristics, were retrieved. The laboratory tests performed prior to surgery included liver function tests, viral hepatitis markers and tumor markers, such as serum $\alpha$-fetoprotein (AFP), carbohydrate antigen 19-9 (CA19-9) and carcinoembryonic antigen (CEA). The imaging examinations included ultrasonography (US), computed tomography (CT), magnetic resonance imaging (MRI) and magnetic resonance cholangiopancreatography (MRCP). After the surgery, the final diagnosis was confirmed by two independent pathologists. All the patients were followed up by telephone communication until the end of this study or until the patients' death, and follow-up data were obtained.

All the study participants, or their legal guardians, provided written informed consent prior to study enrollment. The study was reviewed and approved by the Eastern Hepatobiliary Surgery Hospital Institutional Review Board.

\section{Results}

Patient characteristics. The patients included 7 men and 2 women, aged 35-70 years (mean age, 48.2 \pm 10.5 years). Two patients presented with clinical symptoms, whereas the remaining 7 patients were asymptomatic. Only 1 patient had increased AFP levels $(103.5 \pm 279.1 \mu \mathrm{g} / 1$; normal range, 0-20 $\mu \mathrm{g} / 1), 4$ patients had increased CA19-9 levels 
Table I. Clinical characteristics of patients with bile duct hamartoma.

\begin{tabular}{|c|c|c|c|c|c|c|c|c|c|c|}
\hline $\begin{array}{l}\text { Patient } \\
\text { (n) }\end{array}$ & Sex & $\begin{array}{c}\text { Clinical } \\
\text { symptoms }\end{array}$ & $\begin{array}{c}\text { Age } \\
\text { (years) }\end{array}$ & $\begin{array}{l}\text { AFP } \\
(\mu \mathrm{g} / \mathrm{l})\end{array}$ & $\begin{array}{l}\text { CEA } \\
(\mu \mathrm{g} / \mathrm{l})\end{array}$ & $\begin{array}{c}\text { CA19-9 } \\
(\mu / \mathrm{ml})\end{array}$ & $\begin{array}{c}\text { TBIL } \\
(\mu \mathrm{mol} / 1)\end{array}$ & $\begin{array}{l}\text { ALT } \\
(\mu / 1)\end{array}$ & $\begin{array}{l}\text { AST } \\
(\mu / 1)\end{array}$ & HBsAgt \\
\hline 1 & M & Abdominal pain & 45 & 2.3 & 2.7 & 13.3 & 14.4 & 58.1 & 29.0 & Negative \\
\hline 2 & M & No symptoms & 35 & 9.6 & 2.1 & 49.4 & 7.2 & 37.0 & 24.0 & Positive \\
\hline 3 & M & No symptoms & 70 & 893 & 3.3 & 112.3 & 30.8 & 41.0 & 56.0 & Positive \\
\hline 4 & $\mathrm{~F}$ & No symptoms & 49 & 2.4 & 1.8 & 19.0 & 8.4 & 18.0 & 16.0 & Positive \\
\hline 5 & M & No symptoms & 50 & 3.7 & 3.3 & 36.1 & 13.8 & 36.0 & 21.0 & Positive \\
\hline 6 & $\mathrm{~F}$ & Jaundice & 58 & 2.4 & 4.1 & 878.8 & 192.3 & 86.0 & 65.0 & Negative \\
\hline 7 & M & No symptoms & 41 & 11.2 & 2.4 & 69.2 & 8.1 & 45.0 & 45.0 & Positive \\
\hline 8 & M & No symptoms & 35 & 3.1 & 1.9 & 0.6 & 16.3 & 13.1 & 12.1 & Negative \\
\hline 9 & $\mathrm{M}$ & No symptoms & 51 & 3.4 & 1.9 & 9.9 & 7.9 & 28.0 & 17.0 & Negative \\
\hline
\end{tabular}

AFP, $\alpha$-fetoprotein; CEA, carcinoembryonic antigen; CA19-9, carbohydrate antigen 19-9; TBIL, total bilirubin; ALT, alanine aminotransferase; AST, aspartate aminotransferase; HBsAg, hepatitis B surface antigen; M, male; F, female.

$(132.1 \pm 266.1 \mu \mathrm{g} / \mathrm{l}$; normal range, 0-39 $\mu \mathrm{g} / \mathrm{l}), 2$ patients had increased total bilirubin (TBIL): $33.2 \pm 56.7 \mu \mathrm{mol} / 1$ (normal range, 3.42-20.52 $\mu \mathrm{mol} / \mathrm{l}), 2$ patients had increased alanine aminotransferase (ALT) levels: 40.2 20.7 IU/1 (normal range, 9-50 IU/1) and 3 patients had increased aspartate aminotrans-

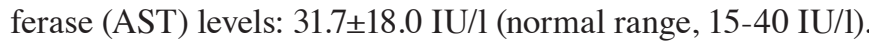
The CEA level was normal $(2.6 \pm 0.8 \mu \mathrm{g} / 1$; normal range, $0-10 \mu \mathrm{g} / \mathrm{l}$ ), and the majority of the patients had normal hepatic function. Five cases were positive for hepatitis B surface antigen. These results demonstrated that the BDH patients had no typical clinical symptoms or laboratory test data (Table I).

Imaging examinations. Prior to surgery, at least one of the medical imaging modalities was applied. A total of 8 patients underwent US examination and the lesions appeared as hypoechoic, hyperechoic and with mixed echogenicity. A total of 5 patients underwent CT examination; in all 5 patients, the lesions were low-density on plain CT, without enhancement in 4 cases and inhomogeneous enhancement in 1 case. A total of 5 patients underwent MRI examination, which revealed hypointensity on T1-weighted imaging (WI) and hyperintensity on T2WI. A total of 4 patients exhibited enhancement and 1 exhibited no enhancement in the arterial phase. Two patients underwent MRCP due to jaundice and intrahepatic bile duct dilation. The preoperative diagnosis was liver cancer in 4 , hepatic hilar biliary obstruction in 1 , chronic calculous cholecystitis in 1 , suspected hepatic abscess in 1 , and benign liver tumor in 2 patients (Table II and Fig. 1). Therefore, it was difficult for the clinicians to reach a definitive diagnosis of BDH without pathological examination, due to the variable appearance of the lesions on imaging.

Pathological characteristics of the patients. All the patients underwent surgery. In one of the patients, during gallstone removal surgery, a small nodule was incidentally discovered, which was pathologically diagnosed as BDH. The majority of the tumors were located in the right lobe. Macroscopically, all the tumors displayed a grayish white surface and they were mostly non-encapsulated. One patient had accompanying liver cirrhosis. The mean tumor diameter was $2.4 \pm 1.8 \mathrm{~cm}$ (range,
0.2-5.8 cm). Microscopically, all cases exhibited bile duct proliferation. Nest-like formations were observed in 2 patients, and in 1 patient the lesion had transformed to intrahepatic cholangiocarcinoma (Table III and Fig. 1). These results indicated that $\mathrm{BDH}$ has the potential to transform into intrahepatic cholangiocancinoma.

Follow-up. At the end of the present study, follow-up data were obtained for all the patients. The patient who was diagnosed with intrahepatic cholangiocancinoma succumbed to the disease 25 months after the operation. The other patients remained alive at the last follow-up and had recovered well.

\section{Discussion}

In the present study, the majority of the patients were asymptomatic and most laboratory test results were considered normal. As shown in Table II, the imaging modalities performed included US, CT, MRI and MRCP. On plain imaging, although the characteristics were variable and atypical, the majority of the lesions exhibited low density on CT, hypointensity on T1WI and hyperintensity on T2WI. As shown in Table III and Fig. 1, 2 cases exhibited partial malignant transformation and in 1 case the BDH transformed into intrahepatic cholangiocarcinoma and the patient succumbed to the disease 25 months after the operation. Therefore, BDH is difficult to diagnose without pathological examination and, once the diagnosis is confirmed, surgical treatment should be preferred due to the potential transformation to cholangiocancinoma.

Several studies reported that a proportion of patients with BDH may present with abdominal distension (6), bacterial infections (7), recurring cholangitis and jaundice (8), and portal hypertension (9). Similarly, 2 patients in our study presented with abdominal pain and jaundice. In the present case series, the majority of the patients had normal liver function tests and tumor marker levels, but 2 patients exhibited increased level of AFP, CA19-9, TBIL and ALT; one was mainly due to liver cirrhosis and portal hypertension, whereas the other one was possibly related to the jaundice. 
Table II. Appearance of bile duct hamartoma on imaging examinations.

\begin{tabular}{|c|c|c|c|c|c|}
\hline Patient (n) & US & $\mathrm{CT}$ & MRI & MRCP & Preoperative diagnosis \\
\hline $1^{\mathrm{a}}$ & ND & ND & ND & ND & Chronic calculous cholecystitis \\
\hline 2 & Hyperechoic & $\begin{array}{l}\text { Low-density on } \\
\text { plain CT; no } \\
\text { enhancement in } \\
\text { arterial phase }\end{array}$ & ND & ND & Liver cancer \\
\hline 3 & $\begin{array}{c}\text { Mixed } \\
\text { echogenicity, } \\
\text { intrahepatic bile } \\
\text { duct dilation }\end{array}$ & $\begin{array}{l}\text { Low-density on } \\
\text { plain CT; no } \\
\text { enhancement } \\
\text { in arterial phase }\end{array}$ & $\begin{array}{l}\text { Hypointense on T1WI, } \\
\text { hyperintense on T2WI, } \\
\text { enhancement in arterial } \\
\text { phase }\end{array}$ & ND & Liver cancer \\
\hline 4 & Mixed echogenicity & $\begin{array}{l}\text { Low-density on plain } \\
\text { CT; no enhancement } \\
\text { in arterial phase }\end{array}$ & $\begin{array}{l}\text { Hypointense on T1WI, } \\
\text { hyperintense on } \mathrm{T} 2 \mathrm{WI} \text {, } \\
\text { enhancement in } \\
\text { arterial phase }\end{array}$ & ND & Liver cancer \\
\hline 5 & Hyperechoic & ND & $\begin{array}{l}\text { Hypointense on T1WI, } \\
\text { hyperintense on T2WI, } \\
\text { enhancement in } \\
\text { arterial phase }\end{array}$ & ND & Benign liver tumor \\
\hline 6 & $\begin{array}{l}\text { Intrahepatic bile } \\
\text { duct dilation }\end{array}$ & ND & ND & $\begin{array}{l}\text { Dilated } \\
\text { bile ducts }\end{array}$ & $\begin{array}{l}\text { Hepatic hilar biliary } \\
\text { obstruction }\end{array}$ \\
\hline 7 & Hypoechoic & $\begin{array}{l}\text { Low-density on plain } \\
\text { CT; inhomogeneous } \\
\text { enhancement in } \\
\text { arterial phase }\end{array}$ & ND & ND & Liver cancer \\
\hline 8 & $\begin{array}{l}\text { Hyperechoic, } \\
\text { obscure } \\
\text { boundary }\end{array}$ & $\begin{array}{l}\text { Low-density on plain } \\
\mathrm{CT} \text {; no enhancement } \\
\text { in arterial phase }\end{array}$ & $\begin{array}{l}\text { Hypointense on T1WI, } \\
\text { hyperintense on T2WI, } \\
\text { no enhancement in } \\
\text { arterial phase }\end{array}$ & ND & Hepatic abscess \\
\hline 9 & Hyperechoic & ND & $\begin{array}{l}\text { Hypointense on T1WI, } \\
\text { hyperintense on T2WI, } \\
\text { enhancement in } \\
\text { arterial phase }\end{array}$ & $\begin{array}{l}\text { Dilated } \\
\text { bile } \\
\text { duct }\end{array}$ & Benign liver tumor \\
\hline
\end{tabular}

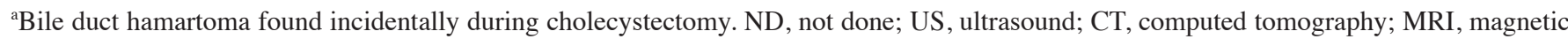
resonance imaging; WI, weighted imaging; MRCP, magnetic resonance cholangiopancreatography.

It has been reported that there are various sonographic appearances of BDH, including hyperechoic, hypoechoic and mixed echogenicity (2,10-13), which is similar to our findings. Wohlgemuth et al (14) hypothesized that the variable sonographic appearance is mainly associated with the different number and size of dilated biliary ducts and degree of liver fibrosis. In 1998, Luo et al strongly recommended that the appearance of multiple comet-tail echoes in the liver may be the characteristic sonographic feature of BDH (15). However, in the present study, there were no signs of multiple comet-tail echoes in any of the patients. We hypothesized that this discrepancy may be attributed to the meagerness of relevant knowledge and the low incidence rate of BDH.

On plain CT, all the lesions exhibited low density, which was consistent with the published literature $(11,13)$. On enhanced CT, the majority of the studies reported that there was no enhancement of BDH due to its poor vascularity (16). In the present case series, 1 patient exhibited inhomogeneous enhancement, which is somewhat similar to two previously reported cases $(17,18)$. All the cases exhibited hypointensity on T1WI and hyperintensity on T2WI, which is similar to previous reports $(11,19,20)$. As regards the enhancement of the lesion on MRI, several studies reported enhancement $(12,14,19,21)$, whereas others reported no enhancement $(11,22,23)$. In the present series, 4 patients exhibited enhancement and 1 patient exhibited no enhancement, which suggests that the presence of enhancement plays no role in the diagnosis of $\mathrm{BDH}$. Compared with $\mathrm{CT}$ and MRI, MRCP exhibits superior sensitivity in identifying bile duct disorders. In the present case series, only 2 patients underwent MRCP, in one of whom a clear cluster of dilated bile ducts without any communication with the main biliary system was observed, appearing to be a BDH.

The exact pathogenesis of $\mathrm{BDH}$ remains unclear and it is usually considered as a cluster of benign liver malformations and ductal plate maldevelopment (13). Whether BDH has malignant potential remains controversial. BDH was previously considered as a benign liver tumor that should be 
Table III. Pathological characteristics of the patients with bile duct hamartomas.

\begin{tabular}{|c|c|c|c|c|c|c|}
\hline Patient (n) & $\begin{array}{l}\text { Location } \\
\text { (segment) }\end{array}$ & $\begin{array}{l}\text { Pathological } \\
\text { diagnosis }\end{array}$ & $\begin{array}{l}\text { Size } \\
(\mathrm{cm})\end{array}$ & $\begin{array}{c}\text { Gross } \\
\text { appearance }\end{array}$ & $\begin{array}{l}\text { Microscopic } \\
\text { manifestations }\end{array}$ & Follow-up \\
\hline 1 & $\mathrm{~V}$ & $\mathrm{BDH}$ & $0.3 \times 0.3$ & Grey-white nodule & Bile duct proliferation & Alive \\
\hline 2 & VI & $\begin{array}{l}\text { BDH, partial } \\
\text { malignant } \\
\text { transformation }\end{array}$ & $3.2 \times 2.6$ & $\begin{array}{l}\text { Grey-white nodule, } \\
\text { no capsule }\end{array}$ & $\begin{array}{l}\text { Bile duct proliferation, } \\
\text { partly nest-like } \\
\text { arrangement }\end{array}$ & Alive \\
\hline 3 & V & $\begin{array}{l}\text { BDH, partial } \\
\text { malignant } \\
\text { transformation }\end{array}$ & $1.2 \times 1.0$ & $\begin{array}{l}\text { Grey-white nodule, } \\
\text { liver cirrhosis }\end{array}$ & $\begin{array}{l}\text { Bile duct proliferation, } \\
\text { partly nest-like } \\
\text { arrangement, liver cirrhosis }\end{array}$ & Alive \\
\hline 4 & VIII & $\mathrm{BDH}$ & $1.4 \times 1.2$ & $\begin{array}{l}\text { Grey-white nodule, } \\
\text { no capsule }\end{array}$ & Bile duct proliferation & Alive \\
\hline 5 & VIII & $\mathrm{BDH}$ & $1.4 \times 1.1$ & Grey-white nodule & Bile duct proliferation & Alive \\
\hline 6 & III & $\mathrm{BDH}$ & $0.2 \times 0.2$ & Grey-white nodule & Bile duct proliferation & Alive \\
\hline 7 & VI & $\begin{array}{l}\text { Intrahepatic } \\
\text { cholangiocarcinoma, } \\
\text { partial BDH }\end{array}$ & $5.8 \times 4.1$ & $\begin{array}{l}\text { Grey-white nodule, } \\
\text { no capsule }\end{array}$ & $\begin{array}{l}\text { Obvious atypical cells, } \\
\text { invasive growth, partly } \\
\text { bile duct proliferation, } \\
\text { cholangiocarcinoma }\end{array}$ & Deceased \\
\hline 8 & IV & $\mathrm{BDH}$ & $4.0 \times 2.8$ & $\begin{array}{l}\text { Grey-white nodule, } \\
\text { no capsule }\end{array}$ & Bile duct proliferation & Alive \\
\hline 9 & $\mathrm{~V}$ & $\mathrm{BDH}$ & $4.0 \times 3.7$ & $\begin{array}{l}\text { Grey-white nodule, } \\
\text { no capsule }\end{array}$ & Bile duct proliferation & Alive \\
\hline
\end{tabular}
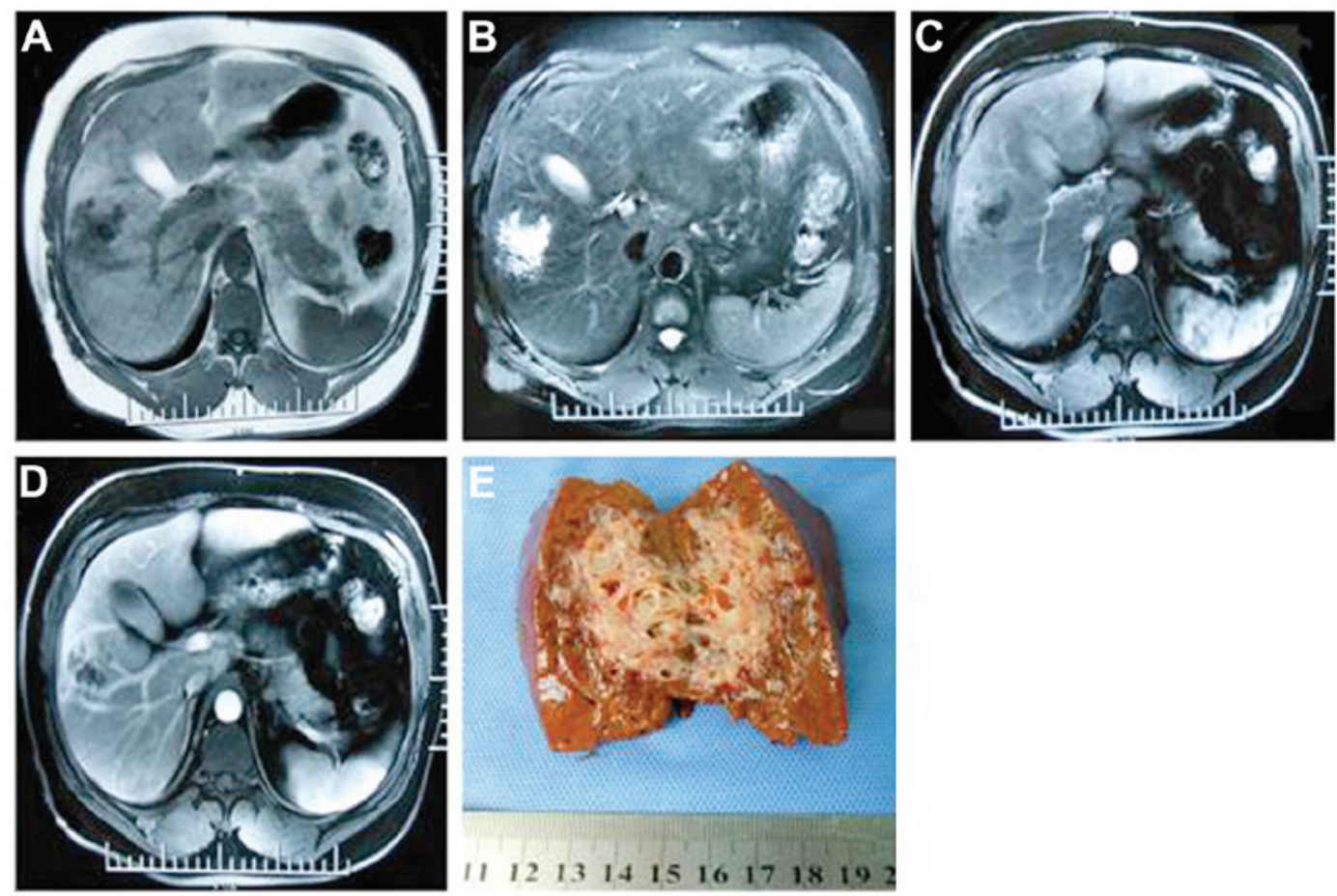

Figure 1. Magnetic resonance imaging and macroscopic appearance of bile duct hamartoma. (A) T1-weighted imaging (WI); (B) T2WI; (C) arterial phase; (D) portal venous phase; and (F) gross specimen.

followed regularly $(11,24-26)$. However, an increasing number of cases indicated that BDH may transform to cholangiocarcinoma and hepatocellular carcinoma $(3,4,10,27-29)$. In the present case series, 3 patients exhibited malignant transforma- tion, one of whom succumbed to the disease 25 months after the operation. The findings of the present study indicate that $\mathrm{BDH}$ has malignant potential and must be resected when the diagnosis is definitive. 
In summary, BDH may transform into cholangiocarcinoma, which is a life-threatening malignancy; thus, BDH should be resected if the lesion is operable. More cases should be investigated to elucidate the mechanism underlying the transformation of $\mathrm{BDH}$ to cholangiocarcinoma.

\section{Acknowledgements}

The present study was funded by the Nursery Project of the Second Military Medical University (grant no. 2014QN19).

\section{References}

1. von Meyenburg H: Uber die Cystenleber. Beitr Pathol Anat 64: 477-532, 1918 (In German).

2. Singh Y, Cawich SO, Ramjit C and Naraynsingh V: Rare liver tumor: Symptomatic giant von Meyenburg complex. J Surg Case Rep 2016: pii: rjw195, 2017.

3. Kim HK and Jin SY: Cholangiocarcinoma arising in von Meyenburg complexes. Korean J Hepatol 17: 161-164, 2011.

4. Parekh V and Peker D: Malignant transformation in von-meyenburg complexes: Histologic and immunohistochemical clues with illustrative cases. Appl Immunohistochem Molecul Morphol: AIMM 23: 607-614, 2015.

5. Gupta A, Pattnaik B, Das A and Kaman L: Von Meyenburg complex and complete ductal plate malformation along with Klatskin tumour: A rare association. BMJ Case Reports 2016 : 10.1136/bcr-2016-215220, 2016.

6. Chandramouleeswari K, Anita S and Shivali B: Mesenchymal hamartoma of the liver: A case report. J Clin Diagn Res 6: $1552-1554,2012$

7. Hashimoto M, Ouchi M, Norose J, Suda FS, Suzuki K, Matsumura N, Lgari Y, Suzuki T, Nakano H, Mizuse M, et al: Bile duct hamartomas (von Meyenburg complexes) associated with a bacterial infection: Case report of elderly diabetic patient. Geriatr Geront Int 11: 534-536, 2011.

8. Sinakos E, Papalavrentios L, Chourmouzi D, Dimopoulou D, Drevelegas A and Akriviadis E: The clinical presentation of Von Meyenburg complexes. Hippokratia 15: 170-173, 2011.

9. Cnossen WR and Drenth JP: Polycystic liver disease: An overview of pathogenesis, clinical manifestations and management. Orphanet J Rare Dis 9: 69, 2014

10. Xu AM, Xian ZH, Zhang SH and Chen XF: Intrahepatic cholangiocarcinoma arising in multiple bile duct hamartomas: Report of two cases and review of the literature. Eur J Gastroenterol Hepatol 21: 580-584, 2009 .

11. Lung PF, Jaffer OS, Akbar N, Sidhu PS and Ryan SM: Appearances of von meyenburg complex on cross sectional imaging. J Clin Imaging Sci 3: 22, 2013.

12. Shin YM: Biliary hamartoma presented as a single mass. Korean J Hepatol 17: 331-334, 2011.

13. Shi QS, Xing LX, Jin LF, Wang H, Lv XH and Du LF: Imaging findings of bile duct hamartomas: A case report and literature review. Int J Clin Exp Med 8: 13145-13153, 2015.

14. Wohlgemuth WA, Böttger J and Bohndorf K: MRI, CT, US and ERCP in the evaluation of bile duct hamartomas (von Meyenburg complex): A case report. Eur Radiol 8: 1623-1626, 1998.

15. Luo TY, Itai Y, Eguchi N, Kurosaki Y, Onaya H, Ahmadi Y, Niitsu M, Tsunoda HS. Von Meyenburg complexes of the liver: imaging findings. J Comput Assist Tomogr 22: 372-378, 1998.

16. Zheng RQ, Zhang B, Kudo M, Onda $\mathrm{H}$ and Inoue $\mathrm{T}$ : Imaging findings of biliary hamartomas. World J Gastroenterol 11: 6354-6359, 2005.
17. Suzuki H, Tsurita G, Ishihara S, Akahane M, Kitayama J and Nagawa H: Resovist-enhanced MRI for preoperative assessment of colorectal hepatic metastases: A case of multiple bile duct hamartomas associated with colon cancer. Case Rep Gastroenterol 2: 509-516, 2008.

18. Patel S, Rajalakshmi BR and Manjunath GV: Histopathologic findings in autopsies with emphasis on interesting and incidental findings-a pathologist's perspective. J Clin Diagn Res 10: EC08-EC12, 2016

19. Gong J, Kang W and Xu J: MR imaging and MR Cholangiopancreatography of multiple biliary hamartomas. Quant Imaging Med Surg 2: 133-134, 2012.

20. Lin S, Weng Z, Xu J, Wang MF, Zhu YY and Jiang JJ: A study of multiple biliary hamartomas based on 1697 liver biopsies. Eur J Gastroenterol Hepatol 25: 948-952, 2013.

21. Saidi RF, Yoon V, Jabbour N, Shah SA and Bozorgzadeh A: Liver transplantation from a donor with multiple biliary hamartomata. Int J Organ Transplant Med 4: 35-37, 2013.

22. Barboi OB, Moisii LG, Albu-Soda A, Ciortescu I and Drug V: Biliary hamartoma. Clujul Med 86: 383-384, 2013.

23. Yamada N, Sanada Y, Katano T, Tashiro M, Hirata Y, Okada N, Ihara Y, Miki A, Sasanuma H, Urahashi T, et al: Pediatric living donor liver transplantation for congenital hepatic fibrosis using a mother's graft with von Meyenburg complex: A case report World J Gastroenterol 22: 9865-9870, 2016.

24. van Vlerken LG, van Leeuwen MS, Schipper ME and van Erpecum KJ: The 'Von Meyenburg complex': An unusual cause of cholangitis? Clin Res Hepatol Gastroenterol 35: 762-764, 2011.

25. Ioannidis O, Iordanidis F, Paraskevas G, Ntoumpara M, Tsigkriki L, Chatzopoulos S, Kotronis A, Papadimitriou N, Konstantara A, Makrantonakis A, et al: Incidentally discovered white subcupsular liver nodules during laparoscopic surgery: Biliary hamartoma and peribiliary gland hamartoma. Klin Onkol 25: 468-470, 2012.

26. Patel SR, Misra V, Verma K, Gupta $P$ and Dhingra V: Benign hepatic mesenchymal hamartoma (HMH) - A case report. J Clin Diagn Res 8: 119-120, 2014.

27. Ettel M, Eze O and Xu R: Clinical and biological significance of precursor lesions of intrahepatic cholangiocarcinoma. World $\mathbf{J}$ Hepatol 7: 2563-2570, 2015.

28. Liu S, Zhao B, Ma J, Li J and Li X: Lesions of biliary hamartoms can be diagnosed by ultrasonography, computed tomography and magnetic resonance imaging. Int J Clin Exp Med 7: 3370-3377, 2014.

29. Lee KB: Histopathology of a benign bile duct lesion in the liver: Morphologic mimicker or precursor of intrahepatic cholangiocarcinoma. Clin Mol Hepatol 22: 400-405, 2016. 